\title{
Modelling Interactions amongst People and Forest Resources at the Landscape Scale
}

\author{
Jerome K. Vanclay ${ }^{1}$ \\ Southern Cross University, PO Box 157, Lismore NSW 2480, Australia \\ Fergus L. Sinclair \\ University of Wales, Bangor, Gwynedd LL57 2UW, UK \\ Ravi Prabhu \\ CIFOR Southern and Eastern Africa Office, 73 Harare Drive, Mount Pleasant, \\ Harare, Zimbabwe
}

FLORES, the Forest Land Oriented Resource Envisioning System, is a framework to facilitate quantitative modelling of ecological, economic and social issues at the landscape scale. This issue of Small-scale Forest Economics, Management and Policy describes the evolution of FLORES from a concept to a series of models calibrated for diverse locations, and documents the lessons learned.

The idea to construct and use landscape-scale models of the forest frontier, based on simulating household decisions and land use at a spatial scale close to the field level, arose from a desire to add rigour to land-use policy research at CIFOR, the Center for International Forestry Research (Vanclay 1995). This simulation modelling approach to addressing interdisciplinary issues, where people are strongly interacting with forest resources, became known as FLORES, the Forest Land Oriented Resource Envisioning System (Vanclay 1998). Muetzelfeldt et al. (1998) constructed a simple prototype of a FLORES model to illustrate the concept and demonstrate the ability of a system-dynamics modelling environment to animate such a model (Muetzelfeldt and Taylor 1997, 2001, Muetzelfeldt and Massheder 2003). In 1999, FLORES became a reality, when 50 scientists from diverse disciplines met in Bukittinggi, Indonesia to construct the first FLORES model styled on this prototype (CIFOR 1999, Vanclay et al. 2003).

\footnotetext{
${ }^{1}$ The research reported in this special issue was made possible by generous financial support from the Department for International Development (UK), the European Community, the Asian Development Bank (under RETA 5812) and the Center for International Forestry Research. The views expressed herein are those of the authors alone. We would like to thank the following people who have assisted in the production of this special issue by acting as anonymous referees for these and other papers: Andy Warner, Brendan Moran, Bruno Verbist, Chris Dake, Chris Legg, Doug Sheil, Euan Mason, Francois Bousquet, Frank Vanclay, Geoff Slaughter, James Gambiza, John Herbohn, John Poulsen, Jungho Suh, Mike Spilsbury, Paul Phillips, Paul van Gardingen, Phil Norman, Philip Nyhus, Roger Wheate, Ross Sigley, Steve Harrison and Tom Evans. Thanks also to the editorial staff, especially Steve Harrison, John Herbohn and Jungho Suh, for making this special issue possible.
} 
The Bukittinggi workshop and the resulting model were small but important steps in the process of establishing procedures, building confidence, proving concepts, fostering software development, and finding a workable approach to a complex problem. One of the less tractable issues that arose from the workshop related to the level of detail: many biophysical modellers intuitively and quickly arrived at a reasonable compromise for sub-models within their own expertise, but tended to become bogged down in detail when assisting others. There was much less previous experience in developing dynamic simulation models of how people made decisions, as influenced by an unfolding social, economic and environmental context. This led to a considerable diversity of opinion about the desired level of detail: for some, the model diagram negotiated at the workshop was a 'horrendogram' that was too complicated to be useful, while others felt that it was 'beginning to approach the complexity required to acknowledge social interactions in the real world'. The diversity of views about the appropriate level of detail persists, and is evident in the contributions to this special issue (e.g. Vanclay 2003, Haggith et al. 2003b).

The Bukittinggi workshop was the beginning, not the conclusion, of work on the Rantau Pandan model. In the three years since the workshop, the model has been enhanced to better represent the intentions of workshop participants, modified to take better account of social interactions (Haggith 1999, Haggith et al. 2003a), and tested in relation to local circumstances and perceptions (Joshi 2000). While the model was not developed to a stage where it could have been adopted by local planners, much has been learned from the process (Vanclay et al. 2003). The experience has guided the development of FLORES models elsewhere (e.g. Legg 2003, Prabhu et al. 2003) and stimulated the development of the FLORES Local Adaptation and Calibration (FLAC) Package (FLORES Society 2001).

The Bukittinggi workshop and the Rantau Pandan model have also inspired alternative approaches to similar issues elsewhere (e.g. Purnomo et al. 2003a). In February 2002, an International Symposium held in Harare (Zimbabwe) provided a forum to share experiences from applying the FLORES approach in diverse situations. Symposium presentations included reports of experiences from Asia (Purnomo et al. 2003b) and Africa (Prabhu et al. 2003), with single (Standa-Gunda et al. 2003) and multiple natural resources (Legg 2003), and with abstract (Haggith and Prabhu 2003, Haggith et al. 2003c) and more concrete concepts (Robiglio et al. 2003). Included in this special issue are selected papers from the Harare symposium that may assist others dealing with similar issues. These papers address a broad range of issues, but all share a common concern for more effective management of people's use of forest resources.

It is somewhat surprising that lessons learned to date from the FLORES experience are not so much about the technical aspects of modelling households and landscapes addressed by Haggith et al. (2003a), but rather more general aspects about managing teamwork (Vanclay et al. 2003), defining problems (Haggith et al. 2003b), and idealizing possible solutions (Haggith and Prabhu 2003). There remain many open questions relating to issues much broader than the specifics of modelling, including questions about the use of forest resources (Standa-Gunda et al. 2003), planning for sustainability (Purnomo et al. 2003b) and about extension and education (Haggith et al. 2003c). 


\section{REFERENCES}

CIFOR (Center for International Forestry Research) (1999), FLORES: A Dynamic Model for Forest and Land-use Decisions, CIFOR Annual Report 1999, CIFOR, Bogor.

FLORES Society (2001), 'FLORES local adaptation and calibration package', FLORES Society, http://www.ierm.ed.ac.uk/flores/ (click 'FLAC Modelling Manual'), accessed 30 January 2003.

Haggith, M. (1999), 'FLORES decision model specification', Unpublished consultancy report prepared by worldforests for CIFOR, Bogor.

Haggith, M. and Prabhu, R. (2003), 'Unlocking complexity: The importance of idealisation in simulation modelling', Small-scale Forest Economics, Management and Policy, 2(2): 293312.

Haggith, M., Muetzelfeldt, R.I. and Taylor, J. (2003a), 'Modelling decision-making in rural communities at the forest margin', Small-scale Forest Economics, Management and Policy, 2(2): 241-258.

Haggith, M., Prabhu, R., Mudavanhu, H., Matose, F., Mutimukuru, T., Nyirenda, R. and StandaGunda, W. (2003b), 'The challenges of effective model scoping: A FLORES case study from the Mafungautsi Forest margins, Zimbabwe', Small-scale Forest Economics, Management and Policy, 2(2): 155-169.

Haggith, M., Prabhu, R., Pierce Colfer, C.J., Ritchie, B., Thomson, A. and Mudavanhu, H. $(2003 \mathrm{c})$, 'Infectious ideas: Modelling the diffusion of ideas across social networks', Smallscale Forest Economics, Management and Policy, 2(2): 225-239.

Joshi, L. (2000), 'Preliminary work on field validation of FLORES household decision model', Unpublished report prepared for the FLORES Society.

Legg, C. (2003), 'Camflores: A FLORES-type model for the humid forest margin in Cameroon', Small-scale Forest Economics, Management and Policy, 2(2): 211-224.

Muetzelfeldt, R. and Massheder, J. (2003), 'The Simile visual modelling environment', European Journal of Agronomy, 18(3-4): 345-358.

Muetzelfeldt, R.I. and Taylor, J. (1997), 'The suitability of AME for agroforestry modelling', Agroforestry Forum, 8(2): 7-9.

Muetzelfeldt, R.I. and Taylor, J. (2001), 'Developing forest models in the Simile visual modelling environment', Paper to IUFRO conference on Forest Biometry, Modelling, and Information Science, Greenwich, June 2001, http://www.ierm.ed.ac.uk/simile/documents/iufro3.pdf, accessed 30 January 2003.

Muetzelfeldt, R.I., Taylor, J. and Haggith, M. (1998), 'Development of pFLORES, a prototype FLORES model', Unpublished consultancy report to CIFOR, Bogor.

Prabhu, R., Haggith, M., Mudavanhu, H., Muetzelfeldt, R.I., Standa-Gunda, W. and Vanclay, J.K. (2003), 'ZimFlores: A model to advise co-management of the Mafungautsi Forest in Zimbabwe', Small-scale Forest Economics, Management and Policy, 2(2): 185-210.

Purnomo, H., Yasmi, Y., Prabhu, R., Yuliani, L., Priyadi, H. and Vanclay, J.K. (2003a), 'Multiagent simulation of alternative scenarios of collaborative forest management', Small-scale Forest Economics, Management and Policy, 2(2): 277-292.

Purnomo, H., Yasmi, Y., Prahbu, R., Hakim, S., Jafar, A. and Suprihatin (2003b), 'Collaborative modelling to support forest management: Qualitative systems analysis at Lumut Mountain, Indonesia', Small-scale Forest Economics, Management and Policy, 2(2): 259-275.

Robiglio, V., Mala, W.A. and Diaw, M.C. (2003), 'Mapping landscapes: Integrating GIS and social science methods to model human-nature relationships in southern Cameroon', Smallscale Forest Economics, Management and Policy, 2(2): 171-120.

Standa-Gunda, W., Mutimukuru, T., Nyirenda, R., Haggith, M. and Vanclay, J.K. (2003), 'Participatory modelling to enhance social learning, collective action and mobilization among users of the Mafungautsi Forest, Zimbabwe', Small-scale Forest Economics, Management and Policy, 2(2): 313-326.

Vanclay, J.K. (1995), 'Modelling to explore land-use patterns at the forest edge: objectives and model design', in P. Binning, H. Bridgman and B. Williams (eds.), Proceedings of 